\title{
Factors affecting the productivity and the efficiency at weaning of hair ewes in a dry tropical environment
}

\author{
Juan Gabriel Magaña-Monforte', Mahmoud Mohamed Nasrat' ${ }^{2}$, Rubén Cornelio Montes-Pérez, \\ Jesús Ricardo Aké-López ${ }^{1}$, José Candelario Segura-Correa ${ }^{1 *}$ \\ ${ }^{1}$ Facultad de Medicina Veterinaria y Zootecnia, Universidad Autónoma de Yucatán, Mérida, Yucatán, México. Apartado Postal 4-116, \\ ${ }^{2}$ Department of Animal Production, Faculty of Agriculture, Assiut University, Assiut, Arab Republic of Egypt
}

\section{A B S TR A C T}

\begin{abstract}
The aim of the study was to evaluate the productivity and efficiency of ewes, relative to the body weight and metabolic body weight in four hair sheep breeds. The dataset included the records of litter size, parity number, birth weight, weaning weight, age at weaning, and ewe body weight (EBW), recorded 24 hours after lambing, from 926 purebred ewes. In total, there were 1,198 lambing records (114, 86 , 434 and 564 for Blackbelly, Dorper, Katahdin and Pelibuey, respectively). Ewe metabolic body weight at lambing was calculated as EBW 0.75 . Ewe productivity was evaluated at weaning, and ewe efficiency as the ratio of $\mathrm{kg}$ of lamb produced at weaning (adjusted at $60 \mathrm{~d}$ of age) divided by ewe body weight or EBW ${ }^{0.75}$, respectively. Katahdin and Dorper ewes had greater body and EBW 0.75 compared to Blackbelly and Pelibuey ewes $(P<0.05)$. There was no difference for those traits between Blackbelly and Pelibuey ewes $(P>0.05)$. Katahdin weaned heavier litters than the other breeds $(P<0.05)$; however, there were no differences between breeds for ewe efficiency at weaning $(P>0.05)$. Third parity ewes were more efficient than both early and late parity ewes $(P<0.05)$. Lambing season was a significant source of variation for ewe efficiency $(\mathrm{P}<0.05)$. Under the conditions of this study, ewe efficiency could be increased by weaning more than one lamb.
\end{abstract}

Keywords: Ewe efficiency; Hair sheep; Metabolic body weight; Pre-weaning traits

\section{INTRODUCTION}

Sheep production represents an important source of protein and income for farmers in the tropics. In the Mexican tropics, sheep production has increased in recent years mostly due to hair sheep adaptability to challenging environmental conditions (de Lucas \& Arbiza 2006; Góngora-Pérez et al., 2010), ability to reproduce throughout the year, high fertility and prolificacy (Notter 2000; Arroyo 2014); as well as parasites resistance (Vanimisetti et al., 2004). However, differences exist among hair sheep. On one hand, Dorper and Katahdin sheep are less resistance to internal parasites than Pelibuey and Blackbelly (Notter 2000; Palomo-Cohuo et al., 2016). On the other hand, adult ewe body size is higher in Katahdin and Dorper than Blackbelly (Notter 2000) and Pelibuey (Chay-Canul et al., 2016).

To improve lamb production, an alternative is to identify maternal breeds with potential to produce heavier litters without increasing production costs. Ewe body weight could aid in identifying and selecting the most efficient ewes in terms of maintenance energy cost for productive and reproductive traits (Dickerson 1978; Nielsen et al., 2013). It has been pointed out that, in sheep, over $60 \%$ of total feed energy is employed for maintenance; and thus, to improve flock efficiency, the level of ewe performance per unit of energy used must be maximized (Dickerson 1978). Assessment of ewe efficiency is commonly carried out through the litter weaning weight (Snyman et al., 1997; Snowder \& Fogarty 2009) or by the ratio of litter weaning weight and body or metabolic body weight of the ewes (Iñiguez \& Hilali 2009; Lôbo et al., 2012). Studies suggest that heavier ewes produce heavier litters (Segura et al., 1996; Hussain et al., 2000; Paputungan \& Makarechian 2000; Petrović et al., 2012) but they have greater maintenance cost and are less efficient when compared to low body weight ewes. In addition, heavy ewes produce less $\mathrm{kg}$ of lamb per unit of body weight (Osoro et al., 1999; Vatankhah \& Salehi 2010; Lobo \& Lobo 2010). Vatankhan (2005) observed

\footnotetext{
*Corresponding author:

José Candelario Segura-Correa, Facultad de Medicina Veterinaria y Zootecnia, Universidad Autónoma de Yucatán, Mérida, Yucatán,

México, Apartado Postal 4-116. E-mail: jose.segura@correo.uady.mx
}

Received: 27 March 2018; $\quad$ Accepted: 18 October 2018 
that the economic value of ewe body weight was low, and in some cases, negative. Furthermore, under extensive grazing systems similar to those found throughout the Mexican tropics, it is impractical to measure nutritional intake, and in consequence maintenance parameters. Litter weaning weight and ewe metabolic body weight $\left(\mathrm{BW}^{0.75}\right)$ ratio could be used as indicators of ewe efficiency without the need to measure feed consumption (Schoeman, 1996) allowing the comparisons of efficiency among different breeds (Nawaz et al., 1999). To maximize genetic gain and reduce production cost, it is of vital importance to identify superior maternal breeds with the greatest productive and reproductive performance and short lambing intervals.

The objective of this study was to determine the effect of some non-genetic factors on litter weight at weaning, and ewe efficiency in four hair sheep breeds.

\section{MATERIALS AND METHODS}

\section{Dataset}

The data used were from a commercial flock located $20^{\circ}$ 58'04" North and 89 37'18' West, Yucatan, Mexico. The dataset includes records from 926 four-purebred hair ewes. In total, there were 1,198 lambing events. Data recorded included litter size at lambing and weaning, parity number, litter lambing weight, litter weaning weight, age at weaning, ewe body weight (EBW) recorded 24 hours after lambing and body condition score using a 5 -point scale (Thompson \& Meyer, 1994), where $1=$ emaciated and $5=$ grossly fat.

\section{Animal husbandry}

Four sheep breeds were evaluated (Katahdin, Pelibuey, Blackbelly and Dorper), which were kept in an area of $83 \mathrm{ha}$, distributed into 55 lots, with irrigation system and under continuous use. Of the 55 lots, 23 were of 0.8 ha each, and used for gestating ewes; 15 lots of 0.8 ha were for replacement ewe lambs, and 17 lots of 0.25 ha each were used for grazing of non-pregnant females during the dry season. The remaining 26 ha had no irrigation and were divided in 26 lots of 1 ha each, and they were used during the rainy season for non-pregnant females. Sheep grazed for 2 days in each lot. Two hectares were used for infrastructure of the farm.

The farm produced its own replacement ewes, being the first selection at weaning (approximately $60 \mathrm{~d}$ of age) and using as criteria that replacements arose from large litters and from dams with short lambing intervals. Around 120 days of age final selection of replacement was based on breed appearance. Replacement ewe lambs entered the breeding herd at 9 months of age and they were housed in a mating batch with older ewes of the same breed.
Replacement females had the same husbandry practices as older ewes. Pregnancy was checked $65 \mathrm{~d}$ after transfer of ewes to the mating batch using an ultrasound images tool. Once pregnancy was confirmed, ewes were moved to a gestation batch where they remained until lambing. Empty ewes remained in the batch for another estrus cycle, and those that fail to get pregnant were culled. Every two weeks, a visual assessment of the gestation batch was done, to identify ewes that were due to lamb in the upcoming days, and were transferred to the lambing pens. Ewes did not receive any sort of assistance at lambing; however, daily visual inspection of the lambing pens was done, to find out if a ewe lambed and to register the lamb born, into the farm database. Furthermore, the daily visual inspection aided to identify non-nursing ewes. When this happened, lambs were moved into individual crates to be hand-fed. One week after lambing, ewes and lambs were kept into lactation pens until weaning ( $60 \mathrm{~d}$ post-partum, approximately). Ewes with poor BCS (i.e., score $<2$ ), based on Thompson \& Meyer (1994) scale of measure, were kept in the lactation lots until their BCS score improved $(>2)$, and then they were moved back to the mating lots.

Even though there was not a specific feeding strategy for replacement ewes, the amount of concentrate (grain) offered was gradually decreased, and grazing time, as well as the amount of cut Taiwan grass (Pennisetum sp.) offered increased from $120 \mathrm{~d}$ of age until lambing. In addition, feeding in the mating and gestation batch was on grazing plus mineral supplementation. In the lambing pens, during the first 4-weeks of lactation, $400 \mathrm{~g}$ of a commercial concentrate feed and $800 \mathrm{~g}$ cut Taiwan grass were offered on a daily basis. From week 5 of lactation until weaning, ewes had restricted $4 \mathrm{~h}$ access to grazing (8:00 am to $12: 00 \mathrm{pm}$ ) per day. Lambs had free access to their dam to nurse, as well as ad libitum access to a commercial pre-started feed (located in a restricted space where only lambs can access), from birth until 4 weeks of age. In addition, lambs were allowed to nurse twice a day, once in the morning (6:00 to 8:00 am) and the other in the afternoon (2:00 to 4:00 pm). Vaccination against Clostridia and Pausteurella and deworming were practiced every 6 months. For deworming, Ivermectin and Closantel sodium were applied.

Traits evaluated were EBW at lambing, ewe metabolic body weight $(\mathrm{EMBW})$ as $\mathrm{EBW}^{0.75}$, adjusted litter weight at $60 \mathrm{~d}$ of age (LWW), weaning weight per $\mathrm{kg}$ EBW (LWW/ EBW) and $\mathrm{kg}$ of weaning weight per kg EMBW (LWW/ (EBW) $^{0.75}$ (Annet et al., 2011; Lôbo et al., 2012). Adjusted litter weaning weight at $60 \mathrm{~d}$ of age (LWW) was calculated as Litter lambing weight ( $\mathrm{kg})+((\mathrm{ADG}), \mathrm{kg})$ x $60 \mathrm{~d})$ ), according to Magaña-Monforte et al. (2013). 
Where:

ADG $=\frac{\left(\begin{array}{l}\text { litterweaningweight,kg- } \\ \text { litter la m bingweight,kg }\end{array}\right)}{\text { Weaningage }}$

\section{Statistical analysis}

Three seasons of lambing were stablished, grouping the months of the year according to climatic characteristics of the region: dry = February to May; rainy = June to October; and, windy and rainy $=$ November to January. Due to little number of observations, ewes with five or more lambing were grouped in one category.

The ratios LWW/EBW and LWW/EMBW included information only of the ewes that weaned at least one lamb. Information of ewes that weaned three or more lambs were deleted due to a little number of observations. Previous analyses showed that first order interaction among main factor were no significant and were not included in the final models. Data were analyzed using general linear model procedures (SAS v9.3; SAS Inst. Inc., Cary, NC) to get least squares means for the traits of interest. Final statistical models included the fixed effects of breed, lambing season, parity number, BCS at lambing and litter size at lambing on EBW traits or litter size at weaning for ewe production traits. When a main effect was a significant source of variation, means from each main effect level were compared using the PDIFF option and a Tukey-Kramer adjustment to account for multiple pairwise comparisons. Results for fixed effects are shown as least-squares means $\pm \mathrm{SE}$.

\section{RESULTS}

\section{Ewe body weight at lambing}

Means and standard deviations (SD) for EBW and EMBW were $41.67 \pm 4.80 \mathrm{~kg}$ (range from 26 to $65 \mathrm{~kg}$ ) and $16.3 \pm$ $1.5 \mathrm{~kg}$ (range from 11.5 to $22.9 \mathrm{~kg}$ ). All the fixed factors included in the statistical analyses were significant, except lambing season (Table 1). At lambing, Katahdin and Dorper ewes were heavier than Blackbelly and Pelibuey ewes $(\mathrm{P}<0.05$, Table 1). EBW and EMBW were highest for ewes with at least five parities, for ewes with BCS $>3$, and for ewes lambing at least two lambs $(\mathrm{P}<0.05$; Table 1$)$.

\section{Ewe efficiency}

Means and SD for LWW, LWW/EBW and LWW/EBW 0.75 were $17.1 \pm 4.6,0.415 \pm 0.115$ and $1.05 \pm 0.29 \mathrm{~kg}$, respectively. For LWW all factors were significant $(\mathrm{p}<0.001)$; however breed had no effect $(\mathrm{P}>0.05)$ on LWW /EBW and LWW/EBW ${ }^{0.75}$ (Table 2). Heavier LWW was associated with higher EBW for Katahdin, but not for

\begin{tabular}{|c|c|c|c|}
\hline FACTOR & $\mathbf{n}$ & EBW & $(E B W)^{0.75}$ \\
\hline Breed & & $P<0.001$ & $P<0.001$ \\
\hline Blackbellly & 73 & $41.62 \pm 0.58^{b}$ & $16.35 \pm 0.17^{b}$ \\
\hline Pelibuey & 409 & $41.96 \pm 0.28^{b}$ & $16.46 \pm 0.08^{b}$ \\
\hline Dorper & 84 & $43.22 \pm 0.54^{a}$ & $16.81 \pm 0.16^{a}$ \\
\hline Katahdin & 395 & $43.65 \pm 0.29^{a}$ & $16.92 \pm 0.08^{a}$ \\
\hline Lambing Season & & NS & NS \\
\hline Dry & 357 & $42.28 \pm 0.29^{a}$ & $16.54 \pm 0.08^{a}$ \\
\hline Rainy & 241 & $42.89 \pm 0.36^{a}$ & $16.77 \pm 011^{\mathrm{a}}$ \\
\hline Windy & 183 & $42.66 \pm 0.39^{a}$ & $16.63 \pm 0.12^{a}$ \\
\hline Parity number & & NS & $P<0.02$ \\
\hline 1 & 240 & $42.41 \pm 0.38^{b}$ & $16.58 \pm 0.11^{\mathrm{b}}$ \\
\hline 2 & 187 & $42.10 \pm 0.41^{b}$ & $16.49 \pm 0.12^{b}$ \\
\hline 3 & 109 & $42.36 \pm 0.49^{b}$ & $16.56 \pm 0.15^{b}$ \\
\hline 4 & 165 & $42.80 \pm 0.42^{\mathrm{ab}}$ & $16.70 \pm 0.13^{a b}$ \\
\hline$>=5$ & 260 & $43.40 \pm 0.33^{a}$ & $16.92 \pm 0.10^{a}$ \\
\hline Body condition score at lambing & & $P<0.0001$ & $P<0.0001$ \\
\hline 1.5 & 206 & $40.12 \pm 0.38^{b}$ & $15.91 \pm 0.11^{b}$ \\
\hline 2.0 & 213 & $39.90 \pm 0.38^{b}$ & $15.84 \pm 0.11^{b}$ \\
\hline 2.5 & 357 & $42.49 \pm 0.31^{b}$ & $16.61 \pm 0.09^{b}$ \\
\hline 3.0 & 120 & $43.70 \pm 0.47^{b}$ & $17.04 \pm 0.14^{b}$ \\
\hline 3.5 & 65 & $46.84 \pm 0.61^{\mathrm{a}}$ & $17.85 \pm 0.18^{a}$ \\
\hline Lambing litter size & & $P<0.0001$ & $P<0.0001$ \\
\hline 1 & 664 & $41.88 \pm 0.25^{b}$ & $16.44 \pm 0.07^{b}$ \\
\hline 2 & 287 & $43.34 \pm 0.35^{a}$ & $16.86 \pm 0.10^{a}$ \\
\hline
\end{tabular}

$\mathrm{n}=$ number of observations; $\mathrm{a}, \mathrm{b}, \mathrm{c}$ letter with different literals within columns are significant at $\mathrm{P}<0.05$ 


\begin{tabular}{|c|c|c|c|c|}
\hline FACTOR & $n$ & WW & WW/EBW & WW (EBW) ${ }^{0.75}$ \\
\hline Breed & & NS & NS & NS \\
\hline Blackbelly & 73 & $18.07 \pm 0.57^{b}$ & $0.436 \pm 0.014^{a}$ & $1.10 \pm 0.03^{a}$ \\
\hline Pelibuey & 409 & $18.26 \pm 0.27^{b}$ & $0.440 \pm 0.006^{a}$ & $1.11 \pm 0.01^{\mathrm{a}}$ \\
\hline Dorper & 84 & $17.96 \pm 0.53^{b}$ & $0.423 \pm 0.013^{a}$ & $1.07 \pm 0.03^{a}$ \\
\hline Katahdin & 395 & $19.27 \pm 0.27^{\mathrm{a}}$ & $0.446 \pm 0.007^{a}$ & $1.41 \pm 0.01 \mathrm{a}$ \\
\hline Lambing season & & $P<0.001$ & $P<0.001$ & $P<0.001$ \\
\hline Dry & 537 & $18.69 \pm 0.29^{a}$ & $0.446 \pm 0.007^{a}$ & $1.13 \pm 0.01^{\mathrm{a}}$ \\
\hline Rainy & 241 & $19.19 \pm 0.35^{a}$ & $0.451 \pm 0.009^{a}$ & $1.15 \pm 0.02^{\mathrm{a}}$ \\
\hline Windy & 183 & $17.28 \pm 0.38^{b}$ & $0.411 \pm 0.009^{b}$ & $1.04 \pm 0.02^{b}$ \\
\hline Lambing number & & $P<0.001$ & $P<0.001$ & $P<0.001$ \\
\hline 1 & 240 & $17.59 \pm 0.38^{b}$ & $0.420 \pm 0.005^{b}$ & $1.06 \pm 0.02^{b}$ \\
\hline 2 & 187 & $18.00 \pm 0.40^{\mathrm{bc}}$ & $0.430 \pm 0.010^{b}$ & $1.09 \pm 0.02^{b}$ \\
\hline 3 & 109 & $19.44 \pm 0.48^{a}$ & $0.465 \pm 0.012^{\mathrm{a}}$ & $1.18 \pm 0.03^{a}$ \\
\hline 4 & 165 & $18.45 \pm 0.41^{\mathrm{ab}}$ & $0.434 \pm 0.010^{b}$ & $1.11 \pm 0.02^{b}$ \\
\hline$\geq 5$ & 260 & $18.45 \pm 0.33^{\mathrm{ac}}$ & $0.430 \pm 0.008^{b}$ & $1.10 \pm 0.02^{b}$ \\
\hline Weaning litter size & & $P<0.0001$ & $P<0.0001$ & $P<0.0001$ \\
\hline 1 & 693 & $15.07 \pm 0.24^{b}$ & $0.366 \pm 0.006^{b}$ & $0.92 \pm 0.01^{b}$ \\
\hline 2 & 268 & $21.70 \pm 0.36^{a}$ & $0.506 \pm 0.008^{a}$ & $1.29 \pm 0.02^{\mathrm{a}}$ \\
\hline
\end{tabular}

$\mathrm{n}=$ number of observations; $\mathrm{a}, \mathrm{b}, \mathrm{c}$ letter with different literals within columns are significant at $\mathrm{P}<0.05$

Dorper ewes, which had heavier EBW. LWW means were similar for Blackbelly and Pelibuey ewes (Table 2). Ewes that lambed in the windy season were less efficient than ewes that lambed in the rainy and dry seasons $(P<0.05$; Table 2). Early parity ewes produced less $\mathrm{kg}$ of lamb at weaning compared with $>3$ parity ewes $(P<0.05)$. Finally, ewes that weaned twins had higher productivity than single lamb ewes $(P<0.05$; Table 2$)$.

\section{DISCUSSION}

The importance of the female adult body weight on efficiency of animal production is widely recognized (Large 1970; Dickerson 1978; Annett et al., 2011; Lôbo et al., 2012). Requirements of maintenance account between 55 to $80 \%$ of the nutritional needs during a production cycle or per year (Large 1970; Keynon et al., 2009).

Breed differences in mature size of ewes could be used to improve performance and productivity of lamb production systems in the tropics. Chay-Canul et al. (2016) summarized adult body weight of some hair sheep breeds in Latin American countries such as Katahdin (55-70 kg), Dorper $(60 \mathrm{~kg})$, Pelibuey $(34 \mathrm{~kg})$ and Blackbelly (32-44 kg) ewes, which agree with previous reports (Wildeus 1977; Notter 2000). Mean body weight of ewes, in this study, which range from 26 to $65 \mathrm{~kg}$, indicates that Blackbelly and Pelibuey ewes were lighter than Dorper and Kathadin. These results follow the same pattern observed by Chay-Canul et al., (2016). However, neither Dorper nor Katahdin body weights reached the means values (Table 1) summarized by Chay-Canul et al., (2016). Under grazing management conditions and minimal supplementation of replacements and adult females during gestation, the latter mentioned authors showed that $80 \%$ of the sheep at lambing registered BCS $<3$ (Table 1) and in consequence the ewes did not reach their mature adult size, as cited by Wildeus (1997) and Notter (2000). EBW ${ }^{0.75}$ means follows the same pattern as EBW of Katahdin and Dorper, which were heavier than Pelibuey and Blackbelly. As pointed out by Large (1970), energy maintenance requirement of a ewe is related to its metabolic size, which in turn will influence productivity and efficiency, measured as LWW, LWW/EBW or LWW / $\mathrm{EBW}^{0.75}$. In addition, these measurements of efficiency can be used as criteria to assess and compare breeds with different body size and weights (Iñiquez \& Hilali 2009; Annet et al., 2011; Lôbo et al., 2012).

Ewe BCS and litter size at lambing had significant effects $(\mathrm{P}<0.05)$ on both $\mathrm{EBW}$ and $\mathrm{EBW}^{0.75}$, but the effects of lambing season and parity number were not significant ( $\mathrm{P}>0.05$; Table 1). BCS is an indicator of the nutritional level, and for a ewe at lambing, it is a reflection of nutritional management during gestation (Kenyon et al., 2009). Ewes with better BCS at calving have higher EBW than those with the low BCS (Kenyon et al. 2009), as shown in the present study. In addition, heavier ewes with good BCS are more likely to have two or more lambs per lambing, as found in the present study (Table 1).

According to Lôbo et al. (2012), ewe efficiency is of vital importance for a profitable flock, which depends on the ewe ability of weaning a lamb, given that LWW is the best single measurement of ewe productivity (Snyman et al., 2007; Snowder \& Fogarty 2009). Several studies have 
shown that larger and heavier ewe breeds with higher milk production produce heavier litters at weaning than the light ones (McGloughlin \& Crowley 1970; Large 1970; Notter 2000; Lôbo et al., 2012). In the present study, Katadhin ewes produced the heaviest LWW even to Dorper ewes, which disagree to the reported by Burge (2005), showing that Katahdin ewes had greater lamb production than Dorper. Cloete et al., (2000) reviewed Dorper performance under a wide range of management conditions and found that average pre-weaning daily gain ranged from 210 to $330 \mathrm{~g} / \mathrm{d}$, which could correspond to $15-22 \mathrm{~kg}$ of individual lamb weaning weight at 60 days of age, compared to almost $18 \mathrm{~kg}$ for LWW in the present study. Other researchers (Nawaz et al., 1999; Matika et al., 2003; Iñiguez \& Hilali 2009; Vatankhah \& Salehi 2010; Lôbo et al., 2012) have used the ratio of litter weight at different stages on EBW and EMBW as a measure of ewe efficiency. Differences among the breeds here studied, suggest that maintenance requirements per ewe are different, because there were no differences for LWW/EBW and LWW/EBW ${ }^{0.75}$. These results disagree to those in the literature (Schoeman 1996; Osoro et al., 1999; Lôbo et al., 2012), where small ewes were more efficient than large ewes. Differences between studies are probably because here, EMBW at lambing was used; whereas Schoeman (1996) used EBW at time of mating. Furthermore, Shoeman (1996) only included records for ewes with single-born lambs whereas in this study ewes with twins were also used. Ewe efficiency at weaning, measured as a ratio, is an accurate measure of ewe's productivity and could be used as criterion to evaluate breed differences to introduce new breeds under conditions similar to the tropics of Mexico. Ewe efficiency at weaning is influenced by factors such as parity number, litter size and climatic season more than in the ewe's ability to wean heavy lambs.

Ewes with less than three parities were less productive and efficient than ewes with more than three parities. Early lambing ewes are still growing and have small uterine capacity (Tuah \& Baah 1985; Benyi et al., 2006), thus, it is not surprising that those ewes were less efficient than ewes that had reached their mature body weight. Gbangboche et al., (2006) observed that the level of ewe productivity increases with parity number.

The effect of lambing season $(<0.05$; Table 2$)$ is basically due to nutritional aspects associated to tropical conditions (Duguma et al., 2002; Magaña-Monforte et al., 2013; Hinojosa-Cuellar et al., 2015; Tec-Canche et al., 2016). Although EBW and EMBW were not different between seasons, ewes lambing in the dry and rainy seasons produced more $\mathrm{kg}$ of lamb at weaning and per $\mathrm{kg}$ EBW or EMBW at lambing. This is explained because such ewes spent pregnancy during the rainy and windy seasons when grass was more abundant, providing the ewes with more feed for themselves and the fetus(es). Conversely, ewes weaning lambs in the windy season were less efficient when their lactation period occurred in the dry season. During the dry season, feed is scarce, whereas in the rainy season, although grass is more abundant, factors such as high precipitations and/or heat would make newborn lambs more susceptible to diseases that could either slow their growth or ultimately lead to death. This in turn would decrease the number of $\mathrm{kg}$ of lamb produced per ewe.

\section{CONCLUSIONS}

Katahdin and Dorper ewes were heavier at lambing, and the former produced heavier litters at weaning, than Blackbelly and Pelibuey ewes, which were less efficient. However, this advantage disappeared when LWW/EBW and LWW/ EMBW was estimated. This suggest that under the present conditions, non-genetic factors such as parity number, nutritional management and environment in general had an important effect on the traits here studied than the breed of the ewe. Therefore, efforts to improve ewe efficiency should be directed to improve management practices to wean more lambs per lambing.

\section{ACKNOWLEDGEMENTS}

The second author thanks to the "Consejo National de Ciencia y Tecnologia (CONACYT-México)" for the scholarship received to carry out his postgraduate studies. The authors would like to thank the personnel from "Rancho Garrido" for their help in this project.

\section{Authors' contributions}

Data were collected and tabulated by Mahmoud Mohamed Nasrat and Rubén Cornelio Montes. Juan Gabriel MagañaMonforte, Jesús Ricardo Aké-López and José Candelario Segura-Correa conducted the statistical analysis and wrote the manuscript. All the authors read and approved the manuscript.

\section{REFERENCES}

Annett, R. W., A. F. Carson, L. E. R. Dawson, D. Irwin and D. J. Kilpatrick. 2011. Effects of breed and age on the performance of crossbred hill ewes sourced from Scottish blackface dams. Animal. 5: 356-366.

Arroyo, J. 2011. Estacionalidad reproductiva de la oveja en México. Trop. Subtrop. Agroecosyst. 14: 829-845.

Benyi, K., D. Norris, N. Karbo, and K. A. Kgomo. 2006. Effects of genetic and environmental factors on pre-weaning and postweaning growth in West African crossbred sheep. Trop. Anim. Health Prod. 38: 547-554.

Burke, J. M. 2005. Lamb Production of Dorper, Katahdin, and St. Croix Bred in Summer, Winter, or Spring in the Southeastern United States, Publications from USDA-ARS/UNL Faculty, 
United States, p.401.

Chay-Canul, A. J., J. G. Magaña-Monforte, L. M. Chizotti, A. T. Piñeiro-Vázquez, J. R. Canul-Solís, A. J. Ayala-Burgos, J. C. Ku-Vera and L. O. Tedeschi. 2016. Energy requirements of hair sheep in the tropical regions of Latin America. Rev. Rev. Mex. Cienc. Pecuarias. 7: 105-125.

Cloete, S. W.P., Snyman, M. A and M. J. Herselman. 2000. Productive performance of dorper sheep. Small Rumin. Res. 36: 119-135.

de Lucas, T. J and A. S. Arbiza. 2006. Situación y perspectivas de la producción de carne de ovino en México. Bayvet. 21: 2228. Available from: http://www.bayersanidadanimal.com.mx/es/ revista-bayvet/index.php.

Dickerson, G. E. 1978. Animal size and efficiency: Basic concepts. Anim. Prod. 27: 367-379.

Duguma, G., S. J. Schoeman, S. W. P. Cloete and G. P. Jordan. 2002. Genetic and environmental parameters for ewe productivity in Merinos. S. Afr. J. Anim. Sci. 32: 154-162. Available from: http:// www.sasas.co.za/genetic-and-environmental-parameters-eweproductivity-merinos.

Gbanboche, A. B., M. Adamou-Ndiaye, A. K. J. Youssao, F. Farnir, J. Detilleux and P. L. Leroy. 2006. Non-genetic factors affecting the reproductive performance, lamb growght and productivity índices of djalzlonke sheep. Small Rumin. Res. 64: 133-142.

Góngora-Pérez, R. D., S. F. Góngora-González, M. A. MagañaMagaña, P. E. y Lara y Lara. 2010. Caracterización técnica y socioeconómica de la producción ovina en el estado de Yucatán, México. Agron. Mesoamerica. 21: 131-144.

Hinojosa-Cuellar, J. A., J. Oliva-Hernández, G. Torres-Hernández, J. C. Segura-Corra and R. y González-Garduño. 2015. Productividad de ovejas F1 pelibuey $x$ blackbelly y sus cruces con dorper y un sistema de producción del trópico húmedo de Tabasco, México. Arch. Med. Vet. 47: 167-174.

Hussain, A., M. E. Babar, S. Ali and Z. Ul-Hasan. 2000. Effect of body weight of ewes on birth weight of lambs in Rambouillet breed of sheep. Pak. J. Biol. Sci. 3: 179-180.

Iñiguez, L. and M. Hilali. 2009. Evaluation of awassi genotypes for improved milk production in Syria. Livest. Sci. 120: 232-239.

Keynon, P. R., H. T. Blair, C. M. C. Jenkinson, S. T. Morris, D. D. S. Mackenzie, S. W. Peterson, E. C. Firth and P. L. Johnson. 2009. The effect of ewe size and nutritional regimen beginning in early pregnancy on ewe and lamb performance to weaning. N. Z. J. Agric. Res. 52: 203-2012.

Large, R. V. 1970. The biological efficiency of meat production of sheep. Anim. Prod. 12: 393-401.

Lôbo, R. N. B., and A. Lôbo. 2010. An Evaluation of the Ratio of Lamb Weight to Ewe Weight as an Indicator of Ewe Efficiency. Proceedings of the $9^{\text {th }}$ World Congress on Genetics Applied to Livestock Production. Leipzig, Germany, p.761-770.

Lôbo, R. N. B., G. A. F. Júnior, A. M. B. Lôbo and O. Facó. 2012. Genetic (co) variance components for ratio of lamb weight to ewe metabolic weight as an indicator of ewe efficiency. Livest. Sci. 143: 214-219.

Magaña-Monforte, J. G., M. Huchín-Cab, R. J. Aké-López and J. C. Segura-Correa. 2013. A field study of reproductive performance and productivity of Pelibuey ewes in Southeastern Mexico. Trop. Anim. Health Prod. 45: 1771-1776.

Matika, O., J. B. Van Wyk, G. J. Erasmus and R. L. Baker. 2003. Genetic parameter estimates in Sabi sheep. Livest. Prod. Sci. 79: 17-28.

McGloughlin, P., and L. P. Crowley. 1970. A comparison of four breeds of sheep as dams for fat lamb production. Ir. J. Agric. Res. 9: 323-331.
Nawaz, M., M. A. Khan, M. A. Qureshi and E. Rasool. 1999. Productive and reproductive performance of Kajli and Lohi ewes. Asian-Australas. J. Anim. Sci. 12: 61-67. https://doi.org/10.5713/ ajas.1999.61.

Nielsen, M. K., M. D. MacNeil, J. C. M. Dekkers, D. H. Jr. Crews, T. A. Rathje, R. M. Enns and R. L. Weaber. 2013. Review: Lifecycle, total industry genetic improvement of feed efficiency in beef cattle: Blueprint for the beef improvement federation. Prof. Anim. Sci. 29: 559-565.

Notter, D. R. 2000. Potential of hair sheep in the United States. J. Anim. Sci. 1977 Suppl 1: 1-8.

Osoro, K., M. Oliván, R. Celaya, and A. Martínez. 1999. Effect of genotype on performance and intake characteristics of sheep grazing contrasting hill vegetation countries. Anim. Sci. 69: 419-426.

Palomo-Cohuo, G. J., A. J. Aguilar-Caballero, J. F. J. Torres-Acosta, and J. G. Magaña-Monforte. 2016. Evaluation of different models to segregate Pelibuey and Katahdin ewes into resistant or susceptible to gastrointestinal nematodes. Trop. Anim. Health Prod. 40: 1517-1524.

Paputungan, U., and M. Makarechian. 2000. The influence of dam weight, body condition and udder scores on calf birth weight and preweaning growth rates in beef cattle. Asian Australas. J. Anim. Sci. 13: 435-439.

Petrović M. P., Caro-Petrović V., Ružić-Muslić D., Ilić Z., Spasić Z., Stojković J. and Milenković, M. 2012. Genetic and phenotypic aspects of the body measured traits in merinolandschaf breed of sheep. Biotechnol. Anim. Husbandry. 28: 733-741.

SAS. 2011. Version. 9.3, SAS Institute INC., Cary, NC, USA.

Schoeman, S. J. 1996. A preliminary assessment of predictive measures for the expression of weaning efficiency in sheep. $\mathrm{S}$. Afr. J. Anim. Sci. 26: 47-49.

Segura, J. C., L. Sarmiento and O. Rojas. 1996. Productivity of Pelibuey and Blackbelly ewes in Mexico under extensive management. Small Rumin. Res. 21: 57-62.

Snowder, G. D., and N. M. Fogarty. 2009. Composite trait selection to improve reproduction and ewe productivity: A review. Anim. Prod. Sci. 49: 9-16.

Snyman, M. A., J. J. Oliver, C. J. Erasmus and J. B. van Wyk. 1997. Genetic parameter estimates for total weight of lamb weaned in Afrino and Mefrino sheep. Livest. Prod. Sci. 48: 111-116.

Tec-Canche, J. E., J. G. Magaña-Monforte, J. C. Segura-Correa. 2016. Environmental effects on productive and reproductive performance of Pelibuey ewes in Southeastern Mexico. J. Appl. Anim. Res. 44: 508-512.

Thompson, J. M. and H. H. Meyer. 1994. Body Condition Scoring of Sheep. Oregon State University, Extension Service, Corvallis, OR.

Tuah, A. K., and J. Baah. 1985. Reproductive performance, preweaning lamb mortality of Dzallonke sheep in Ghana. Trop. Anim. Health Prod. 17: 107-113.

Vanimisetti, H. B., S. P. Greiner, A. M. Zajac and D. R. Notter. 2004. Performance of hair sheep composite breeds: Resistance of lambs to Haemonchus contortus. J. Anim. Sci. 82: 595-604.

Vatankhan, M. 2005. Defining a Proper Breeding Scheme for LoriBakhtiari Sheep in Village System. Ph.D. Thesis. University of Tehran. p.207.

Vatankhah, M., and S. A. Salehi. 2010. Genetic and non-genetic factors affecting Lori-Bakhtiari ewe body weight and its relationship with productivity. Small Rumin. Res. 94: 98-102.

Wildeus, S. 1977. Hair sheep genetic resources and their contribution to diversified small ruminant production in the United States. J. Anim. Sci. 77 Suppl 1: 1-8. 